\title{
THE ADVANTAGES OF THE MICRO EQUITY MODEL FOR MSME BUSINESS RESILIENCE IN YOGYAKARTA DURING PANDEMIC
}

\author{
Bambang Dwi Hartono ${ }^{1^{*}}$, Ahmad Diponegoro ${ }^{2}$, Indra Yuliawan ${ }^{3}$ \\ ${ }^{1,2}$ Graduate School, University of Muhammadiyah Prof. DR. HAMKA, Indonesia \\ ${ }^{3}$ Gajahmada University, Indonesia \\ Email: 'bambang_dh@uhamka.ac.id, ${ }^{2}$ adipone@uhamka.ac.id, ${ }^{3}$ indrayuliawan@yahoo.com \\ *Corresponding author
}

\begin{abstract}
Many MSME business enterprises were severely hit during the Covid-19 pandemic. This study examined a micro equity financing model as an innovative answer to conventional loans in assisting MSME to survive during and after the pandemic. The micro equity financing model employed a profit-sharing system with flexible repayment and without collateral. A qualitative, descriptive data processing approach was employed. Interviews were conducted online with respondents of MSME that use the micro equity model in the Trust Network Finance (TNF) project in Yogyakarta. It was found more than $75 \%$ of MSMEs in Yogyakarta had experienced contractions on the marketing of their business. And more than $50 \%$ of MSME players in Yogyakarta had experienced problems in repaying loans due to the Covid-19 pandemic crisis. We suggested from the results that the micro equity model had shown to provide many benefits to MSME, especially in marketing and financial aspects, such as more accessible loan applications, flexible repayment schedules, and business assistance.
\end{abstract}

Keywords: Micro loan, micro equity, micro-enterprise resilient, islamic finance.

\section{Introduction}

The Indonesian economy has been hit by a crisis since the beginning of 2020, where the impact spread across all countries in the world. What distinguishes it from the economic problem in 1998 and 2008 is the cause. The current cause of the situation is the Covid19 virus, which has spread rapidly and massively across the globe. Moreover, not only have the medium to large-scale enterprises but also the MSME players have been hit. In the 1998 and 2008 crises, they survived because they were not engaged in capital funding from banks. With micro-business financing, development, and government regulations to support MSMEs' access to micro-business loans, most of them have now become more dependent on financing. Thus, the MSMEs were also hit by the current crisis.

The government has made efforts to help MSME players. One of which is to relax financing and loan repayments regulations. However, due to an overly broad impact that disturbs the demand side of the business, the initiative is not yet a comprehensive solution. A Recent evidence-based study found only $17 \%$ of the MSMEs in Indonesia received government assistance during the pandemic, and one of the most critical financial problems many businesses experienced during the pandemic is loan repayment (UNDP \& LPEM FEB UI, 2020).

As a lesson learned from the Covid-19 crisis in Pakistan, Malik et al. (2020) found two things that the government and microfinance agencies needed to do for MSMEs in the future. First, an innovation for the microfinance business model globally was necessary. Second, maintaining the "trust" assets that had been built by the microfinance industry was also essential.

$\mathrm{Lu}, \mathrm{Wu}$, Peng and Lu (2020) also concluded that there were three main ways to relieve cash flow pressure for SMEs in responding Covid-19 pandemic in Sinchuan Province, China: increase revenue, reduce expenses, obtain external financing. The finding is very useful in Indonesia, with many MSME players, which significantly contribute to the economy.

However, there have not been many studies that have tried to explore the potential for new business model innovations as an alternative to conventional microfinance in Indonesia. Traditional microfinance is designed using a loan scheme to provide access to finance for micro-enterprises with few or even no valuable assets that can be used as collateral or financial capital. At the earliest stage of micro enterprises' life cycle, financial capital is the essential resource for acquiring fixed assets, for working capital, for financing operations, and living expenses of the business owners. Financial capital may come from various sources. In developing countries like Indonesia, financial capital is acquired mainly from external sources, predominantly from debt or loans (Parker, 2009). However, Bradley, McMullen, Arts, and Simiyu (2012) revealed that microloan did not always have direct effects on micro enterprises' performance. Still, 
the entrepreneurs' relationship is significant when mediated by the entrepreneur's ability to conduct innovation. The study on Women Micro Enterprises in Indonesia, by Atmadja, Su, and Sharma (2015) showed that there was a negative relationship between microloan (a proxy for financial capital) and SMEs' profit (a proxy for performance), indicating that higher levels of indebtedness were likely to harm performance. One of the reasons is that there is a strong indication that the entrepreneurs cannot productively manage loans for business growth and to enhance profitability (Etemad, 2020). Hence, the relatively high rate of interest imposed on the microloan might burden the micro-enterprises mainly when the loan cannot be optimally used to generate business income. It is also found from the interview that about $88 \%$ of the respondents ranked loan repayment issues as the top problem. This is consistent with recent research findings of Prameka, Sudarmiatin, Wiraguna, Prabowo, and Do (2021) that there were some problems and difficulties that entrepreneurs faced during the Covid-19 pandemic such as financial distress particularly on debt management and inability to pay obligation.

Given the primary goal of microfinance is to reduce poverty through the microloan model for micro-enterprises, it is essential to identify to what extent the success of microfinance is. Thus, relevant policies may be reviewed accordingly. Since existing literature provides inconclusive evidence, this study endeavors to find an alternative model to the conventional micro-loan to help micro-enterprises creating business growth in normal conditions and even creating business resilience during crisis, especially in pandemic Covid-19. This study found a new model for MSME financing based on "Trust". The model was implemented in the Trust Network Finance (TNF) project. This new model innovation provides an alternative business financing for MSMEs that does not depend on loans (microloans) but through equity (micro equity).

\section{MSME Business Growth Constraints}

There are various options for MSME actors to finance their businesses, starting from their capital, selling assets to business financing loans from financial institutions and banks. The choice of massive loans is acceptable by MSME players because the characteristics of the products offered are manageable in terms of requirements and accessibility (Yuliawan, 2017). Especially with the latest technological developments, it is easier for MSME players to get business financing through the fintech platform.
The downside of the ease in financial access is many MSMEs fail to repay their loans since 'easy' loan products require loan repayment in a short period, making it difficult for them to allocate cash and time to fulfill their loan obligations. The lack of capacity of MSME players in managing their businesses and finance lowers their ability to earn enough income to cover costs and develop their business. The MSMEs are left helpless because the agencies providing their loan are not required to assist in fulfilling their obligation to pay back loan principal and interest. Loan providers only encourage MSMEs to fulfill their commitments regardless of profit or loss situation.

\section{Islamic Finance and MSMES}

With Islam as the major religion in Indonesia, the government has encouraged Islamic finance agencies to develop for decades, so the majority of the population is interested in accessing loans to finance more businesses. However, Islamic finance has not grown fast enough in Indonesia. So, it remains small compared to conventional finance. In terms of sharia products, although the types of contracts vary according to consumer needs, it turns out that most Islamic financing only focuses on a kind of contract, namely Murabaha, with a global market share of $75 \%$ (World Bank \& Islamic Development Bank, 2017).

A sharia-compliant evidence-based study in $\mathrm{Mu}$ slim countries suggests that financial principles in sharia challenge the microfinance sector's ability to find sustainably provide sharia-compliant financial products on scale. One of them is the prohibition of interest, which makes conventional microloan models technically impossible. Therefore, there is considerable room for growth because consumers using sharia-compliant products represent less than $1 \%$ of total microfinance outreach (El-Zoghbi \& Tarazi, 2013). This study also elaborates on the context of consumers' demand. The research conducted by Bank Indonesia in West Java and Central Java reflects the low need for sharia products. The West Java study showed that consumers make choices based on proximity and convenience rather than religion. The Central Java study found that consumers required more sensitization to the topic of sharia before any conclusion was drawn about their demand (Seibel, 2008). The El-Zoghbi and Tarazi's research (2013) concluded that Islamic microfinance was still dominated by two contract models, Murabaha and Qard-Hassan (benevolent loan). However, this study also suggested that the profit-and-loss sharing schemes of Musharaka and Mudaraba were the Islamic financial contracts most encouraged by Sharia scholars as best reflecting Sharia principles, though they were not widely offered by Islamic microfinance providers. 
Musharaka, one form of Islamic contract, helps MSME players obtain capital from equity financing that allows both parties to share both profits and losses. This type of contract is expected to be a promising alternative in financing MSMEs' business to conventional, debt-based financing contracts. At the global level, empirical studies have begun to examine equitybased financing by discussing the benefits of profitsharing contracts for MSME players as published in World Bank and Islamic Development Bank reports. Either in the current pandemic crisis and normal conditions, this alternative, sharia-based, micro-financing model is expected to provide a promising solution for all parties, MSME players, loan providers, and the government.

\section{Empirical Study of Micro Equity}

Past research on micro-equity in Germany (Ansari, 2014) states that micro equity can support long-term businesses. It has the potential to improve business management skills because the investors, who have expertise in the industry, not only bring large amounts of capital but they also involve in sharing risks and social motivation that allows micro-entrepreneurs to develop their business. Even previous research in Indonesia (Merkel, 2013) has proven that a microfinance model based on the principle of trust with a profit-sharing scheme can increase risks that are in line with the growth of micro-businesses. Still, it can maintain low levels of non-performing loans. Some of these studies underline the research on the micro equity model innovation in the Trust Network Finance (TNF) project conducted by the researcher.

Based on the empirical study in the TNF project, further research by Meki, Quinn, and Toth (2018) found that the micro-equity model can produce MSMEs that have dynamic souls (dynamic enterprises) to create jobs and welfare. Along with the research in micro-equity models in various countries, a special report by the World Bank (De Mel, McKenzie, \& Woodruff, 2019) stated that the micro equity model of Musharakah contracts could be an alternative to MSMEs business financing. The Musharakah contracts prioritize partnerships and profit-sharing between business actors (Mudharib) and the investor (Shahibul Maal). Recent research on the impact of Covid-19 advised MSME actors to examine their dependence on other parties and start looking for ways to survive in an event such as a pandemic like this (Etemad, 2020).

\section{Research Method}

The proposed research method is a descriptive qualitative approach. It focuses on a clear description of the object of research to get a comprehensive picture of the application of the micro-equity model and its benefits for business resilience during the Covid-19 pandemic crisis, particularly for MSME players participating in the TNF program in Yogyakarta. The research findings were not obtained through quantification procedures, statistical calculations, or other forms of using numerical measures. This study uses several methods by assessing the research results of the target respondents, namely the investee of the TNF program.

The TNF program started in 2017 in Yogyakarta and Central Java province. From a total of 88 TNF in vestees registered in both areas, the study focused on Yogyakarta, which from a total population of 3.6 million people, it has 220,771 MSME players, including from the TNF program. For primary data source, a field study was conducted to collect necessary data by randomly selected 20 samples from investees of the TNF program as respondents. The type of sampling used was purposive sampling because respondents had different characteristics in each category of business type. The type of business of the MSME players participating in the TNF program (investee) in Yogyakarta is production, services, and trading.

Individual Depth Interview (IDI) survey method that runs between 30 to 60 minutes was conducted on each sample from 20 respondents. The IDI approach aims are to explore opinions, behaviors, benefits, and experiences of the investee of micro-equity financing from the TNF program during the pandemic crisis. The research instrument was also formed through the structured interview format by providing structured and unstructured questions. These two types of questions were designed to determine the general understanding of respondents about the differences between the benefits of financing from the micro-equity model and conventional loans (the microloan) for business development, and facing circumstances in the period of crisis, mainly the Covid-19 pandemic. The respondents were interviewed via phone due to the restrictive situation affected by the Covid-19 pandemic. In acquiring secondary data sources, the qualitative methods were carried out through various data collection methods, such as literature study, documentation study, interviews, and discussions.

Based on primary and secondary data, a qualitative through classifying the impacts experienced by MSMEs due to the Covid-19 pandemic was carried out. A more in-depth analysis is carried out to identify the way MSME actors have adapted to the Covid-19 pandemic crisis in managing their product, marketing, and financial part. In the financial aspect, a comparison was made on micro-equity against conventional microloans. The final analysis stage is carried out by processing all the information obtained to focus on the superior elements of each business financing model. 
Based on the problem formulation and explanation of the innovation of the micro-equity model in the TNF project, the objective of this study is to investigate the contribution of the micro-equity model through the TNF program obtained by MSMEs in Yogyakarta to their businesses resilience in facing the Covid-19 pandemic.

\section{Result and Discussion}

According to the method used, the researcher conducted a qualitative analysis based on data processing obtained from primary and secondary data. Secondary data were obtained from a survey conducted by the Yogyakarta Provincial Government on MSME actors.

\section{Secondary Data}

In preliminary observation, the Yogyakarta region was not conducive for MSMEs to run their business normally, where various restrictions were enforced, such as the prohibition of a crowd in some areas including business premises, limiting hours of business activities, and cutting transportation access to various locations. This condition hurts many businesses, especially the MSMEs, that depend on daily sales.

In the context of business growth, there should be a balance between supply and demand so that an optimal price can be formed and business actors can benefit from business development in terms of marketing, efficient production processes, product innovation, and the creation of new jobs. However, actual conditions in the field illustrate a supply-demand balance disorder due to the Covid-19 pandemic. Researchers process the results study achieved by field observations with the survey results conducted by the Yogyakarta provincial government on 2,332 MSME actors engaging in various types of business: production, trade, service, and agriculture businesses. This study focused on the factors that interfere with both the supply and demand sides as well as the financial aspect. Subroto and Ruscitasari (2020) concluded that financial aspects had a positive and significant effect on the performance of MSMEs in the Special Region of Yogyakarta (DIY).

One aspect that disturbs production is the escalation of raw materials' price. Table 1 shows the various rates of increase experienced by MSMEs in Yogyakarta.

The Table 1 shows almost 50\% of MSME players in Yogyakarta have experienced a price increase from $25 \%$ to $50 \%$ during the Covid-19 pandemic. This condition will result in reducing their production capacity and, hence, their decline in profits.
Table 1

Increase Rate in Raw Material Prices in Yogyakarta

\begin{tabular}{lc}
\hline Rate of Increase & Percentage of Cases \\
\hline Same as before the pandemic & $29 \%$ \\
$25 \%-50 \%$ increase & $49 \%$ \\
$50 \%-100 \%$ increase & $21 \%$ \\
$>100 \%$ increase & $2 \%$ \\
\hline
\end{tabular}

The action of reducing production capacity by MSME players will undoubtedly have an impact on business income. The level of production capacity in the field carried out by MSME actors is described in Table 2.

Table 2

Production Capacity of MSMEs in Yogyakarta

\begin{tabular}{lc}
\hline Production Capacity & Percentage of Cases \\
\hline $31 \%-60 \%$ declines & $29 \%$ \\
$>60 \%$ declines & $21 \%$ \\
Temporary production halt & $27 \%$ \\
Higher than before the pandemic & $18 \%$ \\
Same as before the pandemic & $5 \%$ \\
\hline
\end{tabular}

The data above shows that more than $50 \%$ of MSMEs have reduced their production capacity, $30 \%$ to stop operating temporarily. Indeed, operating income is severely reduced. However, a few MSME players can survive, where they can produce at the same capacity as before the pandemic (5\%) and some even higher (18\%). It shows that there are opportunities for MSMEs to survive and grow, especially for business types unaffected by the pandemic crisis.

The demand side from consumers also decreases accordingly, along with the decline of public incomes. So that from the perspective of MSME actors as producers, it will undoubtedly reduce the marketing of products due to the decrease in demand. The condition of business marketing in Yogyakarta province due to the Covid-19 pandemic is shown in Table 3.

Table 3 shows that more than $75 \%$ of MSMEs in Yogyakarta have experienced marketing contractions, ranging from $31 \%$ to a temporary halt.

Table 3

Business Marketing Conditions

\begin{tabular}{lc}
\hline Marketing & Percentage of Cases \\
\hline $31 \%-60 \%$ declines & $28 \%$ \\
$>60 \%$ declines & $24 \%$ \\
No marketing activity & $20 \%$ \\
Temporary production halt & $6 \%$ \\
Higher than before pandemic & $17 \%$ \\
Same as before the pandemic & $4 \%$ \\
\hline
\end{tabular}

Table 4

Sales Partner Conditions

\begin{tabular}{lc}
\hline Impacts & Percentage of Cases \\
\hline Delaying product purchases & $35 \%$ \\
Reducing product purchases & $27 \%$ \\
Stopping product purchases & $20 \%$ \\
Increasing product purchases & $18 \%$ \\
\hline
\end{tabular}


Table 5

\section{Loan Repayment Constraints}

\begin{tabular}{lc}
\hline Impacts & Percentage of Cases \\
\hline On-schedule installments payments & $41 \%$ \\
Deferred installment payments & $36 \%$ \\
Default on installment payments & $15 \%$ \\
Interest only-installments payments & $8 \%$ \\
\hline
\end{tabular}

Table 6

Production Strategy

\begin{tabular}{lc}
\hline Strategic Steps & Percentage of Cases \\
\hline Product Innovation & $78 \%$ \\
Other & $22 \%$ \\
\hline
\end{tabular}

Table 7

Marketing Strategy

\begin{tabular}{lc}
\hline Strategic Steps & Percentage of Cases \\
\hline Look for marketing alternatives & $55 \%$ \\
Optimizing digital marketing & $33 \%$ \\
Others & $12 \%$ \\
\hline
\end{tabular}

In carrying out business marketing, MSME also takes advantage of sales partners to expand its market reach. However, the pandemic crisis has also disturbed the existing business ecosystem, including sales partnerships. Table 4 illustrates the decline in the demand associated with blocks. It is shown the pandemic crisis has caused declines in the demand associated with sales partnerships, such as delaying, reducing, and even stopping product purchases $(82 \%)$.

One of the fastest sources of capital for MSMEs is loans from financial institutions. Nugroho and Negara (2020) found that 75\% of Indonesian MSMEs feared a lack of working capital to maintain or restart their business after the pandemic. However, the pandemic crisis has negatively impacted the ability of the MSME players to pay the loans they made. Table 5 shows that more than $50 \%$ of MSME players in Yogyakarta have experienced problems in repaying loans due to the Covid-19 pandemic crisis, starting from delaying payments to pay installments with only interest.

As entrepreneurs, they must have the ability to survive in adverse circumstances affecting their business. In addition to displaying data on the impact on production and marketing aspects, researchers also reviewed the results of a survey by the Yogyakarta Provincial Government on strategic steps undertaken by MSMEs to minimize the impact of the pandemic. The study remains focused on production and marketing aspects, which are the keys to the success of business growth. Table 6 suggests the strategy from the production aspect.

Table 8

Interference in Marketing and Financial Aspects

\begin{tabular}{|c|c|c|c|}
\hline Type of Business & Sources of Financing & Short-Term Interference & Long-Term Interference \\
\hline $\begin{array}{l}\text { Food processing and } \\
\text { catering services } \\
\text { (Meatballs, Brownies, } \\
\text { Es Kuwut, etc.). }\end{array}$ & $\begin{array}{l}\text { Micro- Equity and } \\
\text { owner's equity. }\end{array}$ & $\begin{array}{l}\text { From the financing aspect, there was } \\
\text { relatively no disturbance. The disturbance } \\
\text { that occurs is a decrease in turnover and } \\
\text { income due to reduced demand because of a } \\
\text { lack of gathering events, e.g., meetings, } \\
\text { celebrations, etc. }\end{array}$ & $\begin{array}{l}\text { Cannot elevate production volume and } \\
\text { expand business network. }\end{array}$ \\
\hline $\begin{array}{l}\text { Fashion / convection } \\
\text { \& tailor. }\end{array}$ & $\begin{array}{l}\text { Micro-Equity and } \\
\text { owner's equity. }\end{array}$ & $\begin{array}{l}\text { Many consumers owe to store owners for } \\
\text { purchases they made at the store. } \\
\text { The banks retain collateral for debt } \\
\text { repayment guarantee. }\end{array}$ & $\begin{array}{l}\text { A capital gap in running the business can } \\
\text { cause the companies to go bankrupt due to } \\
\text { the decline of demands for clothing during } \\
\text { the pandemic. }\end{array}$ \\
\hline Herbal drink. & $\begin{array}{l}\text { Micro-Equity and } \\
\text { cooperative loans. }\end{array}$ & $\begin{array}{l}\text { Relatively no problems in the Micro-Equity } \\
\text { source of financing model. } \\
\text { Many cooperative loans installment cannot } \\
\text { be paid. }\end{array}$ & $\begin{array}{l}\text { The bility to pay debts can be crippled due } \\
\text { to decreased demand. }\end{array}$ \\
\hline $\begin{array}{l}\text { Animal feed and } \\
\text { poultry trade services. }\end{array}$ & Micro-Equity. & $\begin{array}{l}\text { Financially, there is relatively no interference } \\
\text { since there is no burden of paying loan } \\
\text { installments. } \\
\text { Interference occurred due to reduced } \\
\text { demand and limited raw materials. }\end{array}$ & Unable to predict. \\
\hline $\begin{array}{l}\text { Graphic design, } \\
\text { printing, and souvenir } \\
\text { services. }\end{array}$ & $\begin{array}{l}\text { Micro-Equity and } \\
\text { Bank Loan (KUR). }\end{array}$ & $\begin{array}{l}\text { Businesses facing financial problems in } \\
\text { paying loan installments can get deferred } \\
\text { payments of installments up to six months. } \\
\text { Consumer demand for printing products has } \\
\text { fallen dramatically, causing many to switch } \\
\text { to produce or sell face shield. }\end{array}$ & Unable to predict. \\
\hline $\begin{array}{l}\text { Trading and grocery } \\
\text { store. }\end{array}$ & $\begin{array}{l}\text { Micro-Equity and } \\
\text { Bank Loan (KUR). }\end{array}$ & $\begin{array}{l}\text { The ability to pay bank installments is a big } \\
\text { problem. Thus, many diversify their business } \\
\text { lines to other than grocery stores to cover } \\
\text { bank loans. }\end{array}$ & $\begin{array}{l}\text { Unsold goods, the capital did not return, } \\
\text { and the bank loan installments had to be } \\
\text { paid. Businesses can go bankrupt. }\end{array}$ \\
\hline Furniture, trading & $\begin{array}{l}\text { Micro-Equity and } \\
\text { Bank Loan (KUR) }\end{array}$ & $\begin{array}{l}\text { Constraints in paying bank loan installments } \\
\text { amid a decline in demand for furniture } \\
\text { orders }\end{array}$ & \\
\hline
\end{tabular}


Table 9

Types of Adaptation by MSME Actors

\begin{tabular}{|c|c|c|c|}
\hline Type of Business & Product Strategy & Marketing Strategy & Financial Strategy \\
\hline \multirow{4}{*}{$\begin{array}{l}\text { Processed food and } \\
\text { beverages, culinary. }\end{array}$} & Develop more product variants. & Employ social media marketing & Using own capital \& micro-equity. \\
\hline & \multirow{3}{*}{$\begin{array}{l}\text { Pack products into smaller } \\
\text { packaging. }\end{array}$} & (e.g., Instagram \& Facebook). & \multirow{3}{*}{$\begin{array}{l}\text { Borrow from banks and cooperatives } \\
\text { although the risk is high, due to a } \\
\text { relatively large capital requirements. }\end{array}$} \\
\hline & & $\begin{array}{l}\text { Use packaging that more attractive } \\
\text { and more practical. } \\
\text { Deliver products directly to } \\
\text { consumers. }\end{array}$ & \\
\hline & & $\begin{array}{l}\text { Use 'Word of Mouth' marketing } \\
\text { approach. }\end{array}$ & \\
\hline \multirow[t]{2}{*}{ Food stall services. } & $\begin{array}{l}\text { Add more items to the food } \\
\text { menu. }\end{array}$ & $\begin{array}{l}\text { Open stalls early in the morning } \\
\text { because most people are working }\end{array}$ & \multirow[t]{2}{*}{ Saving. } \\
\hline & Adjust the price of products. & from home. & \\
\hline $\begin{array}{l}\text { Animal feed trade } \\
\text { services. }\end{array}$ & Not available. & Use online Marketing approach & Efficiency. \\
\hline $\begin{array}{l}\text { Graphic \& souvenir } \\
\text { design services. }\end{array}$ & $\begin{array}{l}\text { Produce face shields and screen } \\
\text { printing masks because of more } \\
\text { market opportunities. }\end{array}$ & $\begin{array}{l}\text { Sell online and spread 'Word of } \\
\text { Mouth.' }\end{array}$ & Efficiency. \\
\hline \multirow{3}{*}{$\begin{array}{l}\text { Tailor, convection, and } \\
\text { fashion services. }\end{array}$} & Produce face masks or sell & \multirow{3}{*}{$\begin{array}{l}\text { Marketing online, making } \\
\text { 'giveaway' promotions in (buy a } \\
\text { certain amount to get bonus } \\
\text { brooches), conventional 'Word of } \\
\text { Mouth' marketing. }\end{array}$} & Make detailed financial reports. \\
\hline & snacks (e.g., ice cream). & & Apply financial management \\
\hline & $\begin{array}{l}\text { Staying with the same product } \\
\text { despite demand declines. }\end{array}$ & & $\begin{array}{l}\text { knowledge obtained from the training } \\
\text { given by the micro-equity investors. }\end{array}$ \\
\hline Trade, grocery store. & $\begin{array}{l}\text { Find business alternatives, such } \\
\text { as fishing farming, battery } \\
\text { storage services. }\end{array}$ & $\begin{array}{l}\text { Put banners on social media and sell } \\
\text { products directly from door to door. }\end{array}$ & $\begin{array}{l}\text { Look for additional capital from bank } \\
\text { loans. }\end{array}$ \\
\hline Furniture production. & $\begin{array}{l}\text { Keep selling the furniture to } \\
\text { spend out product inventory. }\end{array}$ & $\begin{array}{l}\text { Advertise and sell products through } \\
\text { social media and online marketplace. }\end{array}$ & \\
\hline
\end{tabular}

This data illustrates that most MSME players (78\%) undertake strategic steps by making innovations in producing products and services to survive the crisis caused by the Covid-19 pandemic. This is consistent with results of the study in Yogyakarta of Utomo (2020) that the ability of SME's innovation may improve firm survival during Covid-19 pandemic.

Meanwhile, from the marketing side, MSME players in Yogyakarta have also taken strategic steps, as described in Table 7. The majority of MSME in Yogyakarta undertake strategic actions in the marketing sector in many ways. However, only $33 \%$ of the MSMEs took action utilizing digital marketing, and the rest of MSME carry out their marketing conventionally.

\section{Primary Data}

Researchers conducted a more in-depth study to answer the research objective, "To test whether microequity model through the TNF program obtained by MSMEs in Yogyakarta can contribute to the resilience of their businesses in facing the crisis due to the Covid19 pandemic."

A study was conducted in-depth on 20 MSME respondents who received the benefits of micro-equity in Yogyakarta to obtain primary data. Most of the respondents are business owners with over two years of experience in running their micro-business. Their sole income comes from their business ranging from IDR 1-4 million (USD 70-280) per month. Their monthly revenue from the company ranges from IDR 2 million up to 100 million (USD 140-700) and with its profit ranging from IDR $500,000-3,500,000$ (USD 35-245). Respondents are primarily women (80\%), averaging 35 years old age. Interviews with the respondents were conducted online during the Covid19 pandemic period. Respondents were selected randomly base on their time availability. And it took 40 minutes on average for each interview.

Based on the types of businesses, the 20 MSMEs can be categorized into three types: (a) Production (14 respondents) of goods, which is the majority (70\%). In this category, their business lines are the production of snacks (traditional and modern), food catering, fruit drinks, Muslim apparel, and handicrafts; (b) Trading (4 respondents) of snacks, herbal beverages, groceries, and animal food. Respondents for the type of trading business were four people (20\%); (c) Service (2 respondents) whose type of business is sewing services.

Three categories of problems experienced by MSME actors during the pandemic identified by this research are (1) Loss of demand, resulting in a decrease of sales over $60 \%$; (2) Lack of innovation due to inability to see market opportunities; (3) Constraints on loan repayment for business capital, which may result in collateral confiscation and accumulated debt interest expenses. 
Table 10

Comparison of Financing Models

Micro-Equity Model
Advantages:
1. There is no need to think about both principal and interest loan
installments.
2. No need to use collateral.
3. The profit-sharing principle is relatively fair for both the investor
and the investee.
4. In an economic crisis, micro-equity does not require credit
installments because the scheme principle requires the risks are
shared with the investors.
5. Business relationships are based more on integrity and the
direction of mutual trust.
6. The relationship between the investor and the investee is
relatively equal (not explanative) with the partnership principle.
7. There is a mentoring process.
8. Relatively following the principles of Islamic law because there
is no usury.

Disadvantages:

1. The amount of invested capital is relatively small. Sometimes, it is not following business capital needs

However, this research found some business actors that can identify market opportunities and act accordingly by innovating the packaging and marketing approaches. An example of this instance is a maker of food and soft drink run by a small business in Sleman Regency that modifies packaging and promotes its products in social media, and then proactively delivers orders directly to consumers for free. Another example is a honey seller that, during the Covid-19 pandemic, actively sells his products through social media. Such innovations have enabled MSMEs to sustain their business during declining sales turnover.

\section{Discussion}

This research categorizes the interference experienced by MSMEs during the Covid-19 pandemic in two types, namely: (1) interference that directly hits MSMEs during the pandemic, referred to as short-term disturbances. It affects marketing and financial aspects; (2) interference that has long-term impacts, both during and after the pandemic crisis. It originates from the deteriorating condition of the national and global economy, which affects MSME players.

To assist in understanding and predicting changes in MSME resistance patterns during the Covid-19 pandemic situation, this study maps the types of interference for the MSMEs, as described in Table 8. Note that due to its predictive nature and future changes are very unpredictable, this mapping could be a limitation of this study.

Table 8 presents the short-term and long-term interference for both marketing and financial aspects in MSMEs' business sourced from micro equity and

\section{Conventional Model}

Advantages:

1. The amount of loaned funds is rather large.

2. The relationship between financial institutions and customers is based more on capacity and collateral (the relationships they build are relatively unequal).

Disadvantages:

1. By the time the funds are disbursed the following month, the installments must be paid in a short period, even though a new business is just starting and there is no profit yet.

2. During the Covid 19 pandemic situation, customers are still burdened with loan installments even though there is relief in the form of relaxation in delaying installment payments. However, in principle, the debt must still be repaid even though the business conditions are not favorable for the customer.

3. There is relatively no business assistance. conventional micro-finance (micro-loan). For the food production business, the short-term interference is in the lower-income because the demand is declining due to the regulation that prohibits gathering events such as meetings and celebrations. In the long-term interference, this business will have limited opportunities to expand its production volume and distribution networks. For a fashion business, many of their buyers owe to the store owners despite their assets for collateral are retained by micro-loan providers (short-term interference). In long-term interference, the business owner worried about going bankrupt due to the deep declining demand for clothes from the market. For herbal drink business in short-term interference, relatively has no negative impact on marketing because this product has a high demand for health immunity during the pandemic. However, in financial factors, the business financed by micro-equity has no interference. In contrast, a company financed by conventional microloan potentially cannot make a loan repayment both in the short-term period and in the long-term period. Respectively, trading, service and production business (animal feed, grocery, graphic design, furniture) has similar constraints in repayment loan for MSMEs that financed their business from microloan both at shortand-long-term interference. In contrast, a company financed by the micro-equity relatively has no interference in the financial aspect.

Based on Table 8, the researcher found that whatever the disturbances faced by MSMEs who obtained business capital from outside, it turned out that business financing through the micro-equity model did not cause any obstacles. Meanwhile, business financing that comes from the conventional model (microloan) 
creates many problems, especially when paying principal debt installments and interest. This is consistent with the recent study of Azhari and Wahyudi (2020) found that Islamic banking performance based on debt (loan) financing fluctuated, while the performance based on equity financing experienced growth.

Several respondents expressed their preference for the Micro Equity financing scheme because it is easier to obtain business financing through the microequity scheme than to get the funding from a conventional microloan. Ms. PC, a ground coffee producer, responded in an interview:

"... In terms of proposing a financing application, it is quite easy compared to BRI. Recently, I was offered a loan without collateral from BRI, but I did not take it... The requirements were complicated, and it seems not that good. On the contrary, the Micro Equity repayment is flexible, making it suitable for small businesses. It is just that the loan ceiling is not big enough...". (Interview with PC, 10 December 2020).

Similarly, Mrs. ES, the owner of a sewing service, observed the difference between the micro-equity and the conventional microloan because the microequity has no interest. So, it is more compliant with Islamic rules. The traditional model must be in an orderly manner to pay monthly installments at maturity.

This study also examines the capacity of MSME in responding to the Covid-19 impact to sustain their business. The ability to respond is realized in how the MSMEs adapt to the crisis, depending on the type of business associated with the Strategic Steps taken.

Table 9 illustrates that each MSME actor adapts to the conditions of the Covid-19 pandemic according to their respective types of business by taking strategic steps in the product, marketing, and financial aspects. This research found an interesting fact that the microequity providers provided a workshop on financial management to their clients, which generally the conventional banks do not offer to their clients. The benefits of this training are felt by Mr. MI, who was originally the owner of a clothing embroidery business, now has another company, as he said in an interview:

"... The training provided by TNF Project gave us more knowledge in financial bookkeeping. The follow-up was training in financial management, which helps make my mind grow. In 2016, my initial business was only clothing embroidery. Currently, I have a grocery business, photocopying, battery storage, and fish farming". (Interview with MI, 16 December 2020).

By examining the problems of MSME players in the financial aspect during the Covid-19 pandemic, especially on the business financing, this study found comparable advantages of micro-equity to the conventional models. According to most respondents, the micro-equity model provided more benefits and minimal risks compared to the financing model provided by conventional financial institutions, such as banks, as illustrated in Table 10.

In an interview, a client of the micro-equity scheme, Mrs. RI, a food processing producer, testified as follows:

"When I got a loan from the TNF, I don't have to pay installments immediately in the period following my loan contract. It relieves me. In the $T N F$, the profit-sharing is light and tailored to our abilities, unlike loans at other banks. These are the features that distinguish the micro-equity from other loan models". (Interview with RI, 26 November 2020).

Likewise, the Es Kuwut (Fruit Ice) producer, Mrs. SM, stated that financing through the micro-equity is more flexible, convenient, and profitable than bank loans. This is consistent with the study in Yogyakarta of Hadi and Supardi (2020) concluded that credit policies by banks with lower interest rates and simpler processes, as a result, they will support the acceleration of the revitalization for SMEs.

Apart from being considered more flexible, less risky, and relatively profitable for small business operators, some respondents believed that the TNF model using micro-equity follows Islamic religious principles because it did not contain elements of usury.

Based on the results of research and discussion of studies, researchers have formulated the advantages of the micro-equity model compared to conventional models that contribute to the business resilience of MSME players both before and during the Covid-19 pandemic. This formulation is depicted in Table 11. The table shows a comparison of product features and benefits essential to MSMEs to grow (before the pandemic) and to survive (during the pandemic). The comparison between the microloan and micro-equity models is based on both items. In terms of product features, the required collateral and loan interest are the most concerning issue among MSMEs, where they are not applicable in the micro-equity model. However, the capital acquired by MSMEs is smaller when using microequity compared to the microloan model. The frequent issue observed in the research is repayment constraints. The repayment constraints with low impact on business financed by the micro-equity model are needed by MSMEs to grow and to survive. On the contrary, the microloan creates constraints with high impact for the MSMEs, especially during the pandemic. 
Table 11

Advantages of the Micro-Equity Model for MSME Business Resilience

\begin{tabular}{|c|c|c|c|}
\hline Element of Excellence & & Micro Equity & Microloan \\
\hline \multirow{8}{*}{ Product Features } & Collateral & Not needed & Needed \\
\hline & Interest & Not applicable & Applicable \\
\hline & Loan ceiling & Small & Bigger \\
\hline & Document requirements & Simple & Complex \\
\hline & Repayment schedule & Flexible & Strict (monthly, weekly, daily) \\
\hline & Financial return & $\begin{array}{l}\text { Profit-sharing, with the agreed } \\
\text { ratio }\end{array}$ & $\begin{array}{l}\text { Interest on payable; there may be } \\
\text { changes according to the market. }\end{array}$ \\
\hline & Submission fee & Not applicable & Applicable \\
\hline & $\begin{array}{l}\text { Use of capital for business } \\
\text { turnover }\end{array}$ & $\begin{array}{l}\text { High, because all capital funds are } \\
\text { used for business purposes }\end{array}$ & $\begin{array}{l}\text { Low, because some money must } \\
\text { be set aside for principal and } \\
\text { interest returns. }\end{array}$ \\
\hline \multirow{6}{*}{$\begin{array}{l}\text { Benefits for MSMEs to grow } \\
\text { (before the pandemic) and } \\
\text { survive (during the Covid-19 } \\
\text { pandemic) }\end{array}$} & $\begin{array}{l}\text { Business development } \\
\text { opportunities }\end{array}$ & $\begin{array}{l}\text { High, because the return on capital } \\
\text { is made after there is BEP (break- } \\
\text { even points) }\end{array}$ & $\begin{array}{l}\text { Low, because regardless of the } \\
\text { business success or failure, the } \\
\text { clients still have to pay back the } \\
\text { principal and interest. }\end{array}$ \\
\hline & Profit-sharing & $\begin{array}{l}\text { Applicable, after BEP and can } \\
\text { profit }\end{array}$ & Not applicable \\
\hline & Repayment constraints & $\begin{array}{l}\text { Low, because it is flexible after } \\
\text { BEP }\end{array}$ & $\begin{array}{l}\text { High, there is a risk of collateral } \\
\text { confiscation when the loan } \\
\text { payment is in default (before the } \\
\text { pandemic). }\end{array}$ \\
\hline & & & $\begin{array}{l}\text { Moderate, there is a debt } \\
\text { restructuring program (during the } \\
\text { pandemic). }\end{array}$ \\
\hline & Training and mentoring & Yes, given to all participants & Yes, but rarely \\
\hline & $\begin{array}{l}\text { Business innovation } \\
\text { opportunities }\end{array}$ & $\begin{array}{l}\text { High, because it was taught during } \\
\text { training and mentoring }\end{array}$ & $\begin{array}{l}\text { Low, because exercise is rarely } \\
\text { given }\end{array}$ \\
\hline
\end{tabular}

\section{Conclusions and Implications}

Based on this formulation, the researcher finds the relevance of the implications of this study, such as the product features and benefits for MSMEs given from each model (micro-equity and microloan) have their advantages and disadvantages according to its character. Thus, the researchers made conclusions to answer the formulation of this research problem:

1. The micro-equity model is a business financing innovation for MSMEs that has advantages over conventional models that are beneficial for MSME players in growing businesses before or after the pandemic and maintaining business during the Covid-19 pandemic.

2. The micro-equity model can be an alternative model to conventional microloan facilities for MSMEs because it provides a choice of business financing models according to their respective abilities.

This study also found essential findings related to the discussion of the micro equity model innovation obtained from direct interviews with respondents:

1. MSME actors, in this case as consumers, tend to choose a business financing model based on Islamic law (Sharia principles) because it has elements of justice and equality between entrepreneurs and owners of capital. Moreover, most Muslims in
Indonesia are aware of the sharia rule to avoid elements of usury that come from non-sharia (conventional) financial products.

2. MSMEs can survive the Covid-19 pandemic crisis because they know of innovating business, gained from business training organized by micro-equity providers. After all, it is part of business continuity (sustainability).

This study certainly has limitations regarding sources of information and cases related to the microequity model in other countries and in Indonesia itself. However, the results and findings in this study can contribute to further scientific studies related to entrepreneurship, microfinance, Islamic finance, and public policy.

\section{Acknowledgment}

This research is supported by Research Contract No. 0887.078/I.3/D/2020 from [undisclosed for review purpose].

\section{References}

Ansari, N (2014). Promoting microenterprises through microfinance: Opportunities beyond microcredit. Master thesis, HTW Berlin University, Berlin. 
Atmadja, A. S., Su, J. J., \& Sharma, P. (2015) Examining the impact of microfinance on microenterprise performance (Implications for womenowned enterprises in Indonesia). International Journal of Social Economics, 43(10), 962-981. https://doi.org/10.1108/IJSE-08-2014-0158

Azhari, A. R., \& Wahyudi, R. (2020). Analisis kinerja perbankan syariah di Indonesia: Studi masa pandemi Covid-19. Jurnal Ekonomi Syariah Indonesia, X(2), 67-83. https://doi.org/10.21927/ jesi. 2020.10(2).96 - 102

Bradley, S. W., McMullen, J. S., Arts, K., \& Simiyu, E. M. (2012) Capital is not enough: Innovation in developing countries, Journal of Management Studies, 49(4), 684-717. https://doi.org/10.1111/ j.1467-6486.2012.01043.x

De Mel, S., McKenzie, D. J., \& Woodruff, C. M. (2019). Micro-equity for microenterprises. Policy Research. Retrieved from https://documents.wor ldbank.org/en/publication/documents-reports/do cumentdetail/647381554128100263/micro-equi ty-for-microenterprises

El-Zoghbi, M., \& Tarazi, M. (2013). Trends in shariacompliant financial inclusion. CGAP Focus Note, $84,1-11$.

Etemad, H. (2020). Managing uncertain consequences of a global crisis: SMEs encountering adversities, losses, and new opportunities. Journal of International Entrepreneurship. 18, 125-144. https://link.springer.com/article/10.1007/s10843020-00279-z

Hadi, S., \& Supardi. (2020). Revitalization strategy for small and medium enterprises after corona virus disease pandemic (Covid-19) in Yogyakarta. Journal of Xi'an University of Architecture \& Technology, 12(4), 4068-4076. https://doi.org/1 0.37896/JXAT12.04/1149

Lu, Y., Wu, J., Peng, J., \& Lu, L. (2020). The perceived impact of the Covid-19 epidemic: Evidence from a sample of 4807 SMEs in Sichuan Province, China. Environmental Hazards, 19(4), 323-340. https://doi.org/10.1080/17477891.2020.1763902

Malik, K., Meki, M., Morduch, J., Ogden, T., Quinn, S., \& Said, F. (2020). COVID-19 and the future of microfinance: Evidence and insights from $\mathrm{Pa}$ kistan. Oxford Review of Economic Policy, graa014. https://doi.org/10.1093/oxrep/graa014

Meki, M., Quinn., S., \& Toth, R. (2018). Beyond microcredit: Early evidence on micro equity for the poor in Indonesia. Retrieved from https://skoll centreblog.org/article/beyond-microcredit-earlyevidence-on-microequity-for-the-poor-in-indon esia\#/
Merkel, A. L. (2013). Risk, trust, and contract choice: evidence from a microfinance product in Indonesia. Master thesis, Ludwig-Maximilans-University, Munchen.

Nugroho, Y., \& Negara, S. D. (2020, Oct). COVID19 's impact on micro, small \& medium enterprises and tourism in Indonesia. PERSPECTIVE: ISEAS - Yusof Ishak Institute, 124, 1-11.

Parker, S. C. (2009) The economics of entrepreneurship. New York, NY: Cambridge University Press.

Prameka, A. S., Sudarmiatin, Wiraguna, R. T., Prabowo, S. H. W., \& Do, B. R. (2021). A new strategic business expectancy for MSME sustainability: The impact of uncertainty during the COVID-19 pandemic. KnE Social Sciences, 5(8), 290-299. https://doi.org/10.18502/kss.v5i8.9381

Seibel, H. D. (2008). Islamic microfinance in Indonesia: The challenge of institutional diversity, regulation, and supervision. SOJOURN: Journal of Social Issues in Southeast Asia, 23(1), 86-103. http://dx.doi.org/10.1353/soj.0.0005

Subroto, M. R., S., \& Ruscitasari, Z. (2020). Influence of financial aspects and the use of e-commerce on performance of micro, small, medium enterprises (MSMEs) in Daerah Istimewa Yogyakarta. LPPM UPN "Veteran" Yogyakarta Conference Series Proceeding on Economic and Business Series (EBS), 1(1), 127-134.

UNDP \& LPEM FEB UI. (2020). Impact of COVID19 pandemic on MSMEs in Indonesia. Retrieved from https://www.id.undp.org/content/indonesia/ en/home/library/ImpactofCOVID19MSMEs.html

Utomo, H. S. (2020). The effect of muslim religiosity and innovation capability on firm survival: A study on small enterprise during the Covid-19 pandemic. IQTISHADIA Jurnal Kajian Ekonomi dan Bisnis Islam, 13(2), 179-196. https://doi.org/ 10.21043/istishadia.v13i2.7626

World Bank \& Islamic Development Bank. (2017). Islamic finance: A catalyst for shared prosperity? Retrieved from https://openknowledge.worldban k.org/handle/10986/25738

Yogyakarta Provincial Government-Cooperative and MSMEs Agency. (2020). Survey dampak covid-19 pada umkm. Retrieved from https://sibakuljogja.jogjaprov.go.id/ survey-dampak-covid-19-pada-ukm/hasil. php

Yuliawan, I. (2017) Analisa keunggulan trust network finance sebagai inovasi model pembiayaan micro equity untuk pengembangan wirausaha mikro: Studi di Bogor, Jawa Barat, Indonesia. Master thesis, Universitas Gadjah Mada, Yogyakarta. 